Available online at: http://journal.uinsgd.ac.id/index.php/ks

Khazanah Sosial, Vol. 1 No. 1: 15-31

DOI: $10.15575 / \mathrm{ks} . v 1 \mathrm{i} 1.7142$

\title{
Pola Komunikasi Masyarakat Adat
}

\author{
Ari Wibowo \\ UIN Sunan Gunung Djati Bandung, Indonesia \\ Email:Wibowoa@gmail.com
}

\begin{abstract}
The style of culture, language, and customs of the Rejang tribe show that the Indonesian people have very high local wisdom. The Rejang tribe is also known as one of the oldest tribes in Sumatra. Cultural characteristics, customs and communication patterns of the Rejang tribe are very interesting to be researched and explored deeply. Therefore it is appropriate that the ethnographic method of communication becomes the main basis for in-depth study of the communication patterns of the Rejang tribal community. This research also aims to explain and understand the forms of communication, communication norms, and communication codes that are formed in the traditional wedding ceremony of the Rejang tribe. Qualitative data in this study were obtained through various data collection techniques, such as; interviews with informants, analysis of documents about the geographical and demographic conditions of the Rejang people, observations that have been set forth in the field notes (transcripts). This study also used purposive sampling and snowball sampling techniques. The results of this study indicate that the forms of communication at the traditional ceremony of rejang tribal marriage consist of two forms of communication namely, verbal and nonverbal communication.
\end{abstract}

Keywords: Communication; Rejang tribe; Marriage

\begin{abstract}
ABSTRAK
Corak budaya, bahasa, dan adat istiadat masyarakat suku Rejang menunjukkan bahwa bangsa Indonesia memiliki kearifan lokal yang bernilai sangat tinggi. Suku Rejang juga dikenal sebagai salah satu suku tertua yang ada di Sumatera. Karakteristik budaya, adat istiadat, dan pola komunikasi masyarakat suku Rejang sangat menarik untuk diteliti dan ditelaah secara mendalam. Oleh karena itu tepatlah jika metode etnografi komunikasi menjadi landasan utama untuk mengkaji secara mendalam pola komunikasi masyarakat adat suku Rejang. Penelitian ini juga bertujuan untuk menjelaskan dan memahami bentukbentuk komunikasi, norma komunikasi, dan kode-kode komunikasi yang terbentuk dalam upacara adat perkawinan suku Rejang. Data kualitatif pada penelitian ini diperoleh melalui berbagai macam teknik pengumpulan data, seperti; wawancara dengan narasumber, analisis dokumen tentang kondisi geografis dan demografis masyarakat suku Rejang, observasi yang telah dituangkan dalam catatan lapangan (transkrip). Penelitian ini juga menggunakan teknik purposive sampling dan snowball sampling. Hasil penelitian ini menunjukkan bahwa bentuk-bentuk komunikasi pada upacara adat perkawinan suku rejang terdiri dari dua bentuk komunikasi yakni, komunikasi verbal dan nonverbal.
\end{abstract}

Kata Kunci: Komunikasi ; Suku Rejang ; Perkawinan

\section{PENDAHULUAN}

Indonesia adalah negara yang sangat multietnis dan multikultural. Sebagai negara yang multietnis, Indonesia adalah negara yang terdiri dari ratusan suku yang kemudian menyatu secara politik dalam sebuah payung besar yang bernama Indonesia. M. Junus Melalatoa mencatat lebih dari 300 suku yang ada di Indonesia. Tentu saja jumlah tersebut tidak memperhitungkan suku bangsa lain seperti Cina, Arab, dan lain sebagainya yang juga menetap dan beranak-pinak di Indonesia. Dipertegas pula oleh Koentjaraningrat yang menilai bahwa jumlah suku bangsa di Indonesia sampai saat ini masih sukar

\footnotetext{
* Ari Wibowo

Received: Desember 02, 2019; Revised: January 05, 2019; Accepted: January 15, 2019
} 
ditentukan secara pasti. Hal ini disebabkan ruang lingkup istilah konsep suku bangsa dapat mengembang atau menyempit, tergantung subjektifitas.(Soekanto, 2007)

Mengingat beragamnya suku, adat, agama, bahasa, dan budaya membuat Indonesia dikenal sebagai negara yang sangat multikultural, dengan perbedaan adat-istiadat, unsur-unsur budaya, nilai-nilai budaya, dan tipe-tipe sosial budaya yang berkaitan dengan lingkungan hidupnya. Keragaman tersebut telah menjadi kelebihan utama yang dimiliki Indonesia dibandingkan dengan negara-negara lainnya. Di sisi yang berbeda, keragaman itu seringkali menjadi penyebab munculnya beragam konflik yang ada di Indonesia. Ditambah lagi dengan lemahnya pemahaman masyarakat tentang keragaman budaya, dan adat-istiadat yang berkembang dalam proses interaksi sosial di masyarakat menyebabkan terjadinya distorsi, dan disintegrasi.

Dalam keberagaman budaya kerap kali proses interaksi sosial dan komunikasi menemui masalah atau hambatan-hambatan yang tidak diharapkan sebelumnya. Misalnya saja dalam penggunaan bahasa, lambang-lambang, nilai atau norma-norma masyarakat dan lain sebagainya. Dalam tataran masyarakat adat yang ada di Indonesia, komunikasi dan budaya merupakan satu hal yang tidak dapat dipisahkan. Komunikasi dan budaya mempunyai hubungan timbal balik, seperti dua sisi mata uang. Budaya menjadi bagian dari perilaku komunikasi dan pada gilirannya komunikasi pun turut menentukan, memelihara, mengembangkan, atau mewariskan budaya.

Pada satu sisi, komunikasi juga merupakan suatu mekanisme untuk mensosialisasikan normanorma budaya masyarakat, baik secara "horizontal" dari suatu masyarakat kepada masyarakat lainnya, ataupun secara vertikal dari suatu generasi ke generasi berikutnya. Pada sisi lain, budaya merupakan norma-norma atau nilai-nilai yang dianggap sesuai untuk kelompok tertentu.(Mulyana, 2006)

Terkait mengenai komunikasi dan budaya, ada aspek yang sangat menarik untuk diteliti secara mendalam dan komprehensif, yakni mengenai pola bahasa tutur yang berkembang di masyarakat adat. Bahasa tutur sebagai suatu simbol merupakan salah satu wujud bahwa, manusia adalah makhluk yang berkebudayaan tinggi. Keragaman bahasa tersebut patut menjadi kajian yang sangat menarik untuk diteliti secara mendalam. Hal tersebut karena keragaman bahasa yang ada dalam kelompok masyarakat atau komunitas komunikasi memiliki karakteristik bahasa tutur yang berbeda antara satu dengan yang lainnya. Seperti apa yang dikemukakan oleh W. Edwar Said bahwa, kebudayaan merupakan kesatuan dari gagasan simbol-simbol dan nilai-nilai yang mendasari hasil karya dan perilaku manusia, sehingga tidaklah berlebihan apabila dilanjutkan bahwa begitu eratnya kebudayaan dan simbol-simbol yang diciptakan oleh manusia sehingga manusia disebut sebagai Homo Simbolicum"

Berkenaan dengan hal tersebut maka penelitian tentang bahasa tutur dalam suatu masyarakat adat menjadi layak untuk dikaji secara mendalam, apalagi hidup bermasyarakat memaksa manusia untuk berkomunikasi, baik di lingkungan internalnya maupun dengan masyarakat lainnya. Bertemunya sukusuku dan budaya yang berbeda tentu saja menghadirkan perbedaan-perbedaan, terutama dalam hal bahasa, agama, adat istiadat, norma-norma maupun etos kerja masing-masing. Dalam hal aktifitas keseharian, tentu saja masing-masing melaksanakannya sesuai dengan nilai-nilai dan patokan-patokan yang mencerminkan budaya sukunya.(Koentjaraningrat, 1982)

Dengan bertemunya berbagai kelompok sosial, suku-suku bangsa pada suatu wilayah dapat terjadi dua kemungkinan proses sosial (hubungan sosial atau interaksi sosial), yaitu hubungan sosial yang positif dan negatif. Seperti apa yang nampak pada masyarakat Suku Rejang di Desa Batu Dewa Kecamatan Curup Utara Kabupaten Rejang Lebong yang secara demografi berpenduduk multikultur. Kemudian secara demografis Desa Batu Dewa memiliki kenyataan dan keadaan penduduk yang memiliki keragaman suku, budaya, agama dan ras, bahkan data kependudukan selalu dinamis. Diketahui jumlah penduduk Desa 
Batu Dewa sesuai dengan laporan bulanan data kependudukan adalah berjumlah 1135 jiwa, terdiri dari laki-laki berjumlah 551 jiwa dan perempuan berjumlah 584 jiwa.

Berdasarkan observasi awal dilapangan diketahui bahwa, Desa Batu Dewa adalah salah satu desa yang masyarakatnya heterogen dan multikultur. Beragam etnis, suku, dan agama yang terdapat di desa ini hidup rukun dan damai. Masyarakat desa ini hidup secara berdampingan dan penuh toleransi.

Mempertegas hal tersebut Pemerintah Desa Batu Dewa menerangkan bahwa, di desa ini belum pernah terjadi konflik yang mengandung unsur SARA. Penduduk asli yang bersuku Rejang menerima dengan baik kedatangan warga yang bersuku Jawa, Sunda, Batak, dan Minang atau penduduk asli yang mayoritas beragama Islam menyambut dengan baik warga pendatang yang berbeda suku, budaya dan agama sejak tahun 1977 hingga sekarang. Padahal jika merujuk apa yang disampaikan Wiese dan Becker dalam Soekanto bahwa, perbedaan antara individu-individu, perbedaan kebudayaan, perbedaan kepentingan, dan perubahan sosial dapat melatarbelakangi terjadinya konflik di masyarakat.(Soekanto, 2007) Hal tersebut tentu mengundang pertanyaan tentang pola komunikasi seperti apa yang dibangun oleh masyarakat Suku Rejang sehingga perilaku komunikatifnya mampu meredam konflik.

Selain itu, salah satu perilaku komunikatif masyarakat suku Rejang yang menarik ialah tentang semboyan "pat sepakat mo sepermo" yang dijiwai oleh masyarakat suku Rejang sebagai identitas kultural yang harus dijunjung tinggi oleh masyarakat Rejang dimana pun mereka berada, dan menjadi aturan hidup bagi mereka dalam berinteraksi dengan masyarakat lainnya.

Hingga sekarang suku Rejang menempati Kabupaten Rejang Lebong, Kabupaten Kepahiang, dan kabupaten Lebong. Dialek bahasa yang digunakan penutur bahasa Rejang, jauh berbeda dengan bahasa Melayu dan bahasa daerah di Sumatera lainnya. Kekhasan bahasa Rejang yang berbeda daripada bahasa lainnya juga sangat menarik perhatian untuk diteliti secara mendalam. Hal tersebut karena Bahasa Rejang memiliki perbedaan dalam penuturan dialek bahasa.

Dialek Rejang Kepahiang berbeda dengan dialek Rejang Curup di Kabupaten Rejang Lebong, dialek Rejang Bengkulu Utara (identik dengan dialek Rejang Curup), dan dialek Rejang Lebong di Kabupaten Lebong.Dialek dalam bahasa Rejang terdiri dari : 1) dialek Rejang Kepahiang; 2) dialek Rejang Curup; 3) dialek Rejang Lebong. Dari tiga pengelompokan dialek Rejang tersebut, saat ini Rejang terbagi menjadi Rejang Kepahiang, Rejang Curup, dan Rejang Lebong. Meskipun dialek dari ketiga bahasa Rejang tersebut relatif berbeda, tapi setiap penutur asli bahasa Rejang dapat saling memahami walaupun terdapat perbedaan kosa kata pada saat komunikasi berlangsung. Salah satu contoh perbedaan dialek tersebut misalnya dalam mengucapkan kata jangan, dalam dialek Lebong disebut jibeak, dalam dialek Curup disebut ji'beak, sedangkan dalam dialek Kepahiang disebut jikba.(Noer Aly, 2007)

Salah satu bentuk perilaku keberagamaan yang dipengaruhi oleh kultur lokal adalah pola komunikasi adat perkawinan suku Rejang. Menurut Kartini Kartono, perkawinan adalah suatu peristiwa yang secara formal mempertemukan sepasang mempelai atau sepasang calon suami-istri di hadapan penghulu atau kepala agama tertentu, para saksi, dan sejumlah hadirin untuk kemudian disahkan secara resmi sebagai suami-istri dengan upacara-upacara atau ritus-ritus tertentu. Definisi lain dikemukakan oleh Wahbah Zuhaili, perkawinan adalah akad yang telah ditetapkan oleh syar'i, agar seorang laki-laki dapat dapat mengambil manfaat untuk melakukan istimta' dengan seorang wanita atau sebaliknya.(Aini, 2009) Menurut Sayuti Thalib, Perkawinan adalah suatu ikatan perjanjian yang suci kuat dan kokoh yaitu Perkawinan dala Islam juga dikenal dengan ikatan yang kokoh, perjanjian yang berat.(Mistaqon qh.iza) Hal ini sebagaimana wasiat Rasulullah di haji wada" "Aku wasiatkan kalian untuk selalu berbuat baik begitu kata-kata Rasulullah ketika mengingatkan tentang kewajiban dibalik pernikahan. Ada yang harus dijaga dalam perjanjian yang sangat berat ini Mistaqon qh.iza yakni hati yang menerima, jiwayang rela, sikap yang menentramkan, dan 
kesediaan untuk berjuang bersama untuk hidup bersama secara sah antara laki-laki dan seorang perempuan guna membentuk keluarga yang kekal, santun menyantuni, kasih mengasihi tentram dan bahagia. Oleh karena itu, perkawinan pada suku rejang sejak dulu telah dibatasi atau dijaga oleh berbagai ketentuan adat dan dibentengi oleh kekuatan hukum adat maupun hukum agama.

Bagi suku bangsa yang memiliki adat dan budaya, perkawinan merupakan suatu hal yang sangat penting bagi manusia dalam daur kehidupan yang dilaksanakan dalam suatu upacara yang terhormat serta mengandung unsur sakral di dalamnya. Upacara tersebut biasanya diselenggarakan secara khusus, menarik perhatian dan disertai kehidmatan.

\section{METODE PENELITIAN}

Jenis dan pendekatan penelitian ini adalah penelitian kualitatif (Sugiyono, 2013)-interpretatif dengan menggunakan metode etnografi komunikasi.(Mudjiyanto, 2009) Hal tersebut karena metode ini dapat menjelaskan secara rinci suatu hubungan dari kategori-kategori dan data yang ada pada masyarakat suku Rejang. Hal ini sesuai dengan tujuan dari studi etnografi komunikasi yakni untuk menggambarkan, menganalisis dan menjelaskan perilaku komunikasi masyarakat suku Rejang.

Hal tersebut sesuai dengan dasar pemikiran etnografi komunikasi, yang menyatakan bahwa saluran komunikasi yang berbeda akan mengakibatkan perbedaan struktur berbicara, dan kebudayaan yang ada pada masyarakat suku Rejang.(Munir, 2015) Penelitian yang berparadigam kualitatif ini diharapkan dapat menuntun studi tentang metode etnografi komunikasi dalam memahami bagaimana bahasa, komunikasi, dan kebudayaan masyarakat suku Rejang saling bekerja sama untuk menghasilkan perilaku komunikasi yang khas.

\section{HASIL DAN PEMBAHASAN}

\section{Bentuk Komunikasi dalam Upacara Adat Perkawinan Suku Rejang.}

Perkawinan pada suku Rejang pada asalnya adalah perkawinan eksogami yaitu perkawinan diluar petulai, atau clan.(Hamzah, 2010) Hal ini terbukti dengan adanya perkawinan Biku Bermano dengan Putri Senggang dari Petulai tubei, Perkawinan Biku Bembo dari Petulai Juru kalang dengan Putri Jenggai dari Petulai bermani dan Perkawinan Rio Taun dari Petulai Juru Kalang dengan Putri Jinar Anum dari Petulai Tubei.(Muridan, 2007)

Perkawinan eksogami pada suku Rejang pada awalnya berbentuk kawin jujur kemudian muncul pula bentuk Perkawinan Semendo disebabkan oleh pengaruh dari Minangkabau Sumatera Barat kedua model perkawinan tersebut dikenal istilah asen beleket dan asen semendo.

Perkawinan jujur adalah seorang perempuan/wanita masuk dalam keluarga laki-laki, baik tempat tinggal maupun sistem kekerabatannya. Konsekuensi perkawinan ini ialah terputusnya ikatan pihak perempuan terhadap sanak keluarganya, karena pihak perempuan masuk kedalam anggota keluarga pihak laki-laki dan betempat tinggal secara viripokal di rumah pihak laki-laki. Asen Beleket ini terbagi dua yaitu ; leket putus dan leket coa putus (tidak putus). Leket putus artinya uang jemput serta cakkreciknya diambil semua sekaligus oleh orang tua atau wali perempuan. Hal ini berakibat hubungan perempuan/wanita yang menikah terputus dengan orang tuanya atau keluarganya. Pada upacara perkawinan jujur berlaku temetok bes (memotong rotan), di mana perempuan/wanita tersebut menjadi hak penuh bagi keluarga pihak laki-laki. Apabila suaminya meninggal terlebih dahulu maka ia tetap tinggal di lingkungan keluarga laki-laki. Biasanya wanita tersebut dinikahkan dengan saudara suaminya tanpa 
membayar uang apa-apa. Sistem perkawinan ini menunjukkan sistem kekerabatan patrilineal yang menghitung garis keturunan dari pihak laki-laki.

Adapun Leket coa putus artinya adalah pada saat basen atau penyerahan uang jumputan ada beberapa cekrecik tidak diambil oleh orang tua atau wali perempuan. Sehingga masih ada ikatan berupa uang belum lunas. Oleh sebab itu apabila pihak orang tua perempuan ada kesulitan dia masih berhak untuk minta pertolongan kepada pihak laki-laki. Atau sebaliknya perempuan boleh pulang ke rumah orang tuanya pada saat-saat penting dan mendesak.

Model perkawinan Jujur atau asen beleket menunjukkan satu hubungan kekerabatan yang kekal dengan konsekuensi kaum kerabat laki-laki berkewajiban kepada pihak perempuan. Laki-laki harus menyerahkan mas kawin berupa uang leket dan barang leket.

Dalam perkembangan berikutnya, karena susahnya mencari Barang Leket, akhimya diganti dengan sejumlah uang. Faktor uang tersebut melatar belakngi pemerintah Belanda melarang perkawinan Jujur di seluruh wilayah jajahannya pada tanggal 23 Desember 1862 yang diumumkan di Bijblad no. 1328. Kemudian pada tanggal 10 April 1911 atas kcsepakatan kepala Marga dan kepala pasar yang dipimpin Kontrlir Belanda Swaab dibentuklah aturan adat kawin cerai, sehingga dalam aturan baru ini tidak ditemukan lagi hentuk perkawinan Jujur. Pelarangan ini menganggap ada unsur perdagaigan, karena perempuan beleket dibeli dengan sejumlah uang. Pelarangan perkawinan jujur dengan alasan demikian dibantah Hazairin dan Abdulah Siddik.

Dalam buku Kelepeak Ukum Adat Kabupaten Rejang Lebong dinyatakan tentang penyelesaian kawin jujur (peloroak beleket) disebutkan betimbang besayang, nenek ngen lengan negong samei-samei, peyambung nybei ngen asep opoi dik timboa, tematoa ga is aduk (kesayangan seseorang harus dipertimbangkan, berat dan ringan dikerjakan bersama-sama. Anak dan basil perkawinan, mengikuti garis keturuanan suami). Tiep-tiep asen beleket, nikeak umeak smanei (setiap rasan kawin jujur, pemikahan dilaksanakan di rumah pihak laki-laki).

Pada saat ini, akibat dinamika perkembangan zaman, sistem perkawinan jujur mulai ditinggalkan oleh keluarga suku Rejang. Karena menurut suku Rejang, adat perkawinan jujur dianggap tidak mampu lagi menampung aspirasi masyarakat, dan dipandang tidak sesuai lagi dengan perkembangan zaman. Menurut informasi seorang informen, Perkawinan Jujur dengan bentuk eksogami yaitu perkawinan di luar petulai sudah tidak berlaku dan tidak dilaksanakan lagi oleh suku Rejang. keluarga suku Rejang boleh menikah dengan sesama petulainya, karena sistem petulai tersebut tidak lagi memiliki ikatan yang cukup kuat dalam suku Rejang".(Ahwan, 2012)

Bentuk perkawinan berikutnya yang belaku pada Suku Rejang adalah sistem Perkawinan Semendo. Perkawinan Semendo adalah suami mengikuti isteri dalam arti suami bertempat tinggal di rumah atau kampung halaman isteri. Sistem perkawinan ini dipenggaruhi oleh adat Minangkabau yang memiliki sistem kekerabatan matrilineal, yang menentukan garis keturunan dari pihak Ibu.

Sistem Perkawinan Semendo terbagi menjadi dua bagian yaitu Semendo Ambil Anak (tambik Anak) dan Semendo rajo-rajo. Sistem Semendo ambil anak terbagi dua yaitu; Semendo ambil anak tidak beradat disebut juga Semendo menangkap hurung terbang (nyep tunakep burung terbang) dan Semendo ambil anak beradat. Selain kedua bentuk Semendo tersebut, dahulu pada masyarakat Rejang juga dikenal Semeno bayar utang dan Semendo langew jio (lalat Hijau).

Dewasa ini Sistem semendo bayar utang sudah tidak berlaku lagi pada suku Rejang. Seorang informan menyatakan bahwa tidak ada lagi suku Rejang yang membayar hutang dengan cara menikahkan anaknya. Sedangkan semendo langew jio masih dapat terjadi, misalnya bila ada suatu aib keluarga yaitu anaknya dihamili oleh keluarganya sendiri, maka untuk menutup aib perempuan tersebut dinikahkan. 
Tetapi dalam kedudukan perkawinannya mengikuti sistem perkawinan semendo rajo-rajo. Hal ini dilakukan demi kemaslahatan suatu keluarga dan untuk menutup aib dan rasa malu.

Bentuk perkawinan berikutnya yang belaku pada Suku Rejang adalah sistem perkawinan Semendo ambil anak. Dalam perkawinan seperti ini, laki-laki semendo dianggap oleh keluarga istri sebagai seorang pendatang yang tidak membawa apa-apa. Laki-laki tersebut biasanya tinggal di rumah perempuan selama-lamanya dan biaya upacara perkawinan ditanggung pihak perempuan/wanita. Apabila terjadi perceraian hidup atau mati semua hak waris jatuh kepada pihak isterinya. Datang dengan tangan kosong pergi dengan tangan kosong pula. Bentuk perkawinan ini merupakan salah satu bentuk perkawinan yang tidak sederajat (sekufu) di mana derajat suami berada lebih rendah dibanding dengan derajat isterinya. Kenyataan ini diperkuat lagi oleh sebutan lain untuk sistem perkawinan ini yaitu; kawin Semendo menangkap burung terbang atau kawin Semendo bapak ayam. Perbedaan beradat dan tidak beradat terletak pada uang pelapik (mas kawin dalam bentuk uang).

Disebut tidak beradat apabila pihak laki-laki tidak memberi uang pelapik. Sedangkan disebut beradat jika pihak 1aki-laki memberikan uang pelapik. Uang Pelapik dapat dibayar penuh, sebagian atau kurang dari separoh. Tetapi bila tidak membayar sedikitpun uang pelapik, kosekuwensinya adalah sermua anak masuk ke dalam pihak keluarga isteri. Jika suami membayar penuh maka dia berhak atas satu anak laki-laki dan seorang anak perempuan. Jika dia hanya membayar separoh/sebagian maka dia hanya berhak atas satu orang anak laki atau satu orang anak perempuan menurut pilihan mereka masingmasing.

Selain sistem perkawinan semendo sebagaimana disebutkan di atas, ada pula model perkawinan semendo yang disebut dengan semendo sementaro (benggen) yaitu semendo terbatas waktu. Misalnya setelah dia mencukur rambut semar anak (pencukuran rambut perdana) atau setelah anaknya dewasa dia boleh membawa isterinya pulang ke lingkungan keluarga asalnya. Namun pada saat awal perkawinan, dia harus bertempat tinggal di lingkungan keluarga pihak istrinya.

Bila di cermati kedua bentuk perkawinan (Semendo ambil anak beradat dan tidak beradat) memiliki corak matrilineal, kendatipun suami masih mempunyai ikatan kekerabatan dengan sanak saudaranya, sehingga ia masih dapat mewarisi ayahnya disamping mendapat warisan dari isterinya. Tata cara penyelesaian adat kawin semendo (Ca o peloroak semendo) dalam Kapeleak Ukum Adat Kabupaten Rejang Lehong, disebutkan;

"Emanie temugheu neak umeak selawie, samei-samei jemago, pitek kinai kaleu si apei mbeak melengan, kaleu si benek mbeak tumambeak, kaleu anak be sa'e tanye magea cakto dukun. Penyambung nyabei ngen asep opoi dik timboa adeba anak perpuan ngen temotoa ga is royot ngenyan. Tiep-üep semendo, nikeak neak umeak selwie.

Anak yang lahir dalam sistem perkawinan Semendo ambil anak beradat dan tidak beradat mengikuti garis keturunan pihak perempuan atau ibu. Setiap perkawinan semendo model ini, akad nikahnya dilaksanakan di rumah pihak calon pengantin perempuan/wanita.

Bentuk perkawinan berikutnya yang belaku pada Suku Rejang adalah sistem perkawinan Semendo rajo-rajo. Perkawinan Semendo rajo-rajo biasanya terjadi apabila status keluarga sama kuat, sehingga dalam waktu asen (mufakat) tidak ada yang mau mengalah, sedang perjodohan tak dapat dihindari, maka terjadilah kedudukan Semendo rajo-rajo. Tempat tinggal setelah menikah diserahkan sepenuhnya kepada kedua mempelai, apakah akan tinggal di rumah pihak keluarga isteri atau pada keluarga suami, atau tinggal di tempat lain.

Pepatah Rejang menyebutkan cacing di mana tangah senook di situ dia berada atau sering disebut di mana nak mencari. Artinya mereka dipersilahkan untuk memilih di mana mau bertempat tinggal ibarat 
cacing di mana tanah dingin di situ mereka berdiam Sedangkan dalam sistem kekerabatan dihitung melalui garis keturuan pihak ayah dan pihak ibu yang disebut dengan bilateral.

Berbagai sistem perkawinan yang telah disebutkan di atas tidak semuanya dilakukan keluarga suku Rejang sekarang ini. Sistem perkawinan Jujur atau Asen Beleket dengan segala variasinya dapat dikatakan tidak berlaku lagi. Sistem perkawinan Semendo dalam bentuk ambil anak dan semendo menangkap burung terbang mengalami hal yang sama. Sekalipun ada tetapi bentuknya sangat terbatas biasanya hanya pada persoalan penetapan tempat tinggal setelah menikah saja.(Morissan, n.d.)

Sedangkan dalam sistem kekerabatan mengakui garis keturunan pihak ayah dan ibunya. Seorang informan menyebutkan ; perkawinan jujur dan semendo menangkap burung terbang sudah tidak pemah lagi dilakukan keluarga Suku Rejang.

Bentuk perkawinan yang lazim dilakukan dewasa ini, adalah perkawinan semendo rajo-rajo, yang memberikan kebebasan kepada kedua mempelai untuk memilih tempat tinggal setelah menikah atau di mana dia ingin mencarai kehidupannya yang lebih layak. Alasan tidak berlakunya bentuk perkawinan jujur dan semendo ambil anak, menurut Zayadi Hamzah, paling tidak ada tiga alasan yaitu, pertama ; perkawianan dengan bentuk jujur dan semendo ambil anak itu tidak sesuai lagi dengan zamannya, kedua, bentuk perkawinan ini terkesan memutuskan hubungan kekerabatan dengan anak, terutama beleket yang pelapiknya dibayar penuh dan ketiga ; kita tidak dapat memaksa anak-anak kita untuk beleket (perempuan) atau semendo (laki-laki) karena mereka sudah pintar memilih bentuk perkawinannya.

Sistem perkawinan yang berlaku sekarang ini adalah sistem perkawinan Semendo rajo-rajo. Sistem ini memberlakukan sistem kekerabatan melalui keturunan ayah dan ibu dan persoalan tempat tinggal diserahkan kepada kedua mempelai. Dalam hal waris mereka dapat mewarisi orang tua masing-masing. Keluarga suku Rejang merelakan sepenuhnya terhadap keputusan anak-anaknya dalam sistem perkawinan Semendo rajo-rajo. Dalam beberapa waktu setelah menikah biasa mereka tinggal di salah satu pihak isteri atau pihak suaminya. Kedua orang tua mereka menerimanya dengan senang hati. Akan tetapi ada pula dalam waktu singkat setelah menikah mereka memilih tinggal di tempat lain.

\section{Bentuk Komunikasi Verbal dan Nonverbal dalam Prosesi Sebelum Perkawinan}

Prosesi Sebelum Perkawinan menurut adat-istiadat suku Rejang ada beberapa tahapan upacara yang mesti dilalui sebelum pelaksanaan prosesi perkawinan. Adapun bentuk komunikasi verbal tersebut adalah; mediak, bekulo, betunang, dan sembeak sujud dan Majok sematen /bakea mengenyan tahapantahapan sebelum perkawinan ini menunjukkan bentuk komunikasi verba dan nonverbal yang menyatu dalam satu rangkaian adat.

\section{Mediak}

Sebelum memasuki tahap perkawinan, suku Rejang mengenal kegiatan pacaran atau pergaulan bujang dan gadis. Menurut adat- istiadat suku Rejang, pemilian jodoh dapat dipilih sendiri oleh bujang dan gadis, melalui suatu proses pacaran untuk saling mengenal antara satu dengan yang lain yang disebut dengan istilah mediak. Selain istilah mediak tahapan ini juga sering disebut dengan belinjang yaitu suatu cara dalam adat Rejang untuk memilih calon suami atau istri sesuai dengan kehendak calon pengantin.

Akan tetapi menurut pengamatan penulis, masih juga ditemukan pemilihan Jodoh bujang dan gadis melalui Asen Tuai (Perjodohan oleh orang tua). Pelaksanaan mediak dilakukan dengan dua cara yaitu secara langsung dan tidak langsung. Secara langsung adalah seorang bujang berpesan kepada seorang gadis pilihannya melalui temannya atau teman si gadis, pesan tersebut berisi ingin mengecek (omongomong) bila pesan telah sampai di sebut dengan berambok. Bila pesan telah sampai si gadis menjawab dengan pesan sindiran yaitu apakah pesan itu tidak nyasar ? Jika pesan tidak kesasar, maka ditunjuklah 
tempat dimana mediak atau berambok dilakukan. Kemudian si bujang mendatangi tempat yang telah disepakati dengan didampingi temannya. Setelah terjadi kata sepakat maka terjadi rambok opot

Dalam adat mediak atau belinjang terdapat beberapa aturan, yang harus dipatuhi yaitu:

Si bujang tidak boleh menggunakan kata-kata kotor, atau kata-kata tidak sopan dalam sendaguraunya dengan si gadis. Jika tata tertip ini tidak dihiraukan oleh si bujang, maka ia akan di hukum karena melanggar adat yang di sebut dengan cepalo mulut;

Si bujang tidak boleh lancang tangan memegang-megang bahagian badan si gadis dalam belinjangnya itu. Jika terjadi hal yang dilarang itu, maka si bujang dapat di hukum karena melanggar adat yang di sebut dengan cepalo tangan;

Mediak atau belinjang tidak diperkenankan ber-khalwat (berduaan saja) setiap pertemuan mereka mesti menyertakan orang lain satu orang laki-laki dan satu orang perempuan. Baik dari keluarga masingmasing atau tidak;

Dilarang melakukan pertemuan di tempat yang tidak semestinya, Misalnya pertemuan di pondok sawah, di hutan atau tempat-tempat lain yang secara etika tidak patut dijadikan tempat pertemuan.(Abdul Aziz Muhammad Azzam, 2009)

Setelah berapa kali mediak (pacaran/kenalan) dan ada penyesuaian, si bujang menawarkan ingin meletakkan uang kepada si gadis, bila ada persetujuan, keduanya menyampaikan kepada temannya masing-masing dan kepada orang tuanya, bahwa besok lusa ia akan meletakkan uang atau menerima uang.

Kadirman menyebutkan jika terdapat kecocokan biasanya si bujang dan si gadis saling memberikan tanda, berupa cincin, kain, baju, dan lainnya yang dilakukan dalam pertemuan wali atau keluarga kedua belah pihak. Benda pemberian sebujang disebut dengan cingan atau gan, sedangkan benda pemberian si gadis disebut dengan ciai

Selain secara langsung seperti disebut diatas ada juga cara mediak yang dilakukan secara tidak langsung. Cara ini dilakukan ketika seorang bujang bertandang kerumah ayah si gadis. Si gadis dipastikan tidak berada di rumah dalam pertemuan tersebut. Si bujang berdialog dengan orang tua si gadis berkisar pada pekerjaan sehari-hari. Umumnya pada persoalan pertanian. Ketika hubungan telah berlanjut cukup lama dan terjadi persesuaian dengan hubungan tersebut maka di sampaikan kepada orang tua si bujang untuk menindak lanjuti perasanan tersebut.

Adat mediak tetap dipertahankan pada sebagian suku Rejang khususnya pada wilayah-wilayah pedesaan. Mediak menurut adat Rejang merupakan wahana tata cara pergaulan bujang dan gadis dalam proses mencari jodoh pada Suku Rejang. Adat ini dapat menjamin dan menghindarkan muda mudi (bujang dan gadis) dari perbuatan-perbuatan yang kurang terpuji dalam proses berpacaran.

\section{Bekulo}

Bekulo pada dasamya merupakan tahapan lanjutan yamg telah disepakati ketika mediak dalam Berambok apa bila telah terjadi kesesuaian hubungan maka dilakukan apa yang disebut dengan sik mengisik maksudnya si bujang mengirim utusan dari keluarganya untuk menanyakan apakah keluarga si gadis mengizinkan anaknya untuk menikah.

Dalam pelaksanaan sik mengisik orang tua bujang bersama keluarganya mendatangi rumah si gadis dengan membawa oleh-oleh. Sampai dirumah si gadis kegiatan di awali dengan menyuguhkan iben penembai kecek yaitu sirih persembahan secara adat untuk memulai bekulo untuk memulai pembicaraan dalam sik mengisik. Sik mengisik merupakan tahab awal sebelum adat bekulo.

Kedatangan utusan si Bujang kepada orang tua si gadis yang disebut dengan mesik asen. Sedangkan tamu yang datang berasan disebut dengan bekulo. Ketika utusan si bujang dating kerumah orang tua si gadis, maka orang tua si gadis wajib menegur atau menyapanya dengan secara adat. Sebelum 
berbicara dwajibkan menyuguhkan Sirih ( $t a^{\prime} a k$ ) setelah menegur dengan sirih, kemudian di suguh-kan kepada tetamu Serawo kepalapo (Sawo nyoa). Setelah menyuguhkan Sirih pembicaraan secara adat dimulai dengan kata-kata "Ini sirih saya tujukan kepada bapak, mohon bapak menerima sirih saya. Setelah bapak makan sirih ada sesuatu yang ingin saya bicarakan" Bagi yang diberi suguhan sirih, diharuskan mencicip (makan sedikit sirih) dengan mengambil sebagian kecil dari daun sirih tersebut. Setelah memakan sirih yang disuguhkan utusan keluarga si bujang kemudian menjelaskan maksud kedatangannya.

Pembicaraan dalam sik mengisik biasanya di lakukan dengan pantun atau sair dari kedua belah pihak, setelah kegiatan ini selesai dan di peroleh kata sepakat maka pihak laki-laki memberikan tanda berupa cincin dan kain yang disebut dengan gan. Setelah berapa hari acara sik mengisik selesai, maka di adakan adat bekulo dengan melibatkan keluarga besar si bujang; yang terdiri dari imam, ketua kutai, rajo, dan badan musawarah adat. Tata cara pelaksanaan bekulo akan menempuh sebanyak dua belas adab sebagai berikut;

Tembei Mengecek dari tukang Bigo (pembawa acara) acara bekulo dimulai dengan membaca lafadz basmalah yaitu (bismilahirrahmanirrahim);

Iben izin magea rajo oleh perwakilan tuan rumah. Sang wakil membawa sirih dengan berbagai perangkatnya menghadap rajo atau kades meminta izin untuk menyapa dan menanyakan maksud kedatangan pihak laki-laki;

Iben ta'ok tawea yakni menyampaikan sirih menyapa tamu yaitu pihak laki-laki, sekaligus menanyakan maksud kedatangannya. Setelah utusan pihak laki-laki menyampaikan maksudnya ingin bertemu puko emuak, tuan rumah, maka dilanjutkan dengan iben izin kundei mandeak magea rajo. Sebagai acara ke-empat yaitu;

Penyampaian sirih minta izin untuk menemui tuan rumah kepada rajo oleh perwakilan pihak lakilaki.

Iben izin kundai mandiakmageak puko umek, penyampaian sirih minta izin untuk bekulo dari pihak laki-laki kepada pihak perempuan.

Wakil pihak perempuan minta izin kepada rajo untuk bekulo juga menyuguhkan sirih. Kemudian pihak laki-laki menghadap tuan rumah (pihak perempuan) untuk menyampaikan maksud kedatangan mereka, memberikan buah tangan, memusawarahkan berbagai biaya peng'as pengindau atau walimah. Setelah ada kesepakatan hasil musyawarah lalu disampaikan kepada rajo pada acara ketujuh;

Yang dinamakan kadeak kadan wakea puko umeak magea rajo oleh wakil tuan rumah.

kadeak kadeu wakea puko emeak magea puko umeak, yakni menyampaikan hasil musyawarah oleh wakil pihak laki-laki kepada pihak perempuan langsung menyerahkan berbagai bahan atau biaya untuk peng'as pengindau yang sudah di serahkan pihak laki-laki.

Putuweak Rajo, yakni pesan-pesan rajo dan langsung mengakui atau meresmikan bahwa akan di adakan bekulo, sehingga bujang dan gadis resmi bertunang secara adat.

Kata sambutan dari pihak perempuan.

Kata sambutan dari pihak laki-laki dan

pembacaan doa.

Adat bekulo merupakan upacara untuk meresmikan pertunangan antara si bujang dan si gadis. Dengan bekulo hubungan bujang dan gadis telah memiliki kekuatan hukum, karena telah melibatkan rajo, BMA, tokoh agama dan masyarakat umum. Bekulo telah menutup bagi laki-laki lain baik secara adat maupun agama untuk meminang gadis tersebut selama belum ada keputusan berpisah. Orang tua kedua 
belah pihak serta masyarakat ikut secara bersama-sama mengawasi pasangan tersebut supaya tidak terputusnya hubungan pertunangan mereka, sehingga sampai pada hari pemikahan.

Dalam pelaksanaan adat bekulo tidak di temukan unsur-unsur budaya lokal yang bertentangan dengan Islam. Dalam pelaksanaan upacara tersebut telah terjadi akomodasi nilai-nilai Islam, sehingga simbol-simbol ke-Islaman menjadi dominan mewamai upacara tersebut. Terjadi penolakan unsur budaya lokal yang bertentangan dengan ajaran Islam. Unsur-unsur Islam yang mengalami akomondasi dalam ritual bekulo adalah adanya bacaan basmalah dan doa selamat pada awal dan akhir kegiatan ritual. Telah terjadi konflik atau penolakan dengan nilai Islam terhadap budya berupa kegiatan meminta izin kepada arwah dan pengormatan dengan membakar kemenyan.

Kegiatan tersebut sekarang sudah ditinggalkan karena bertentangan dengan Islam. Adanya bacaan basmalah dan doa selamat berbahasa Arab dalam ritual bekulo yang dilakukan Suku Rejang menunjukkan indikasi adanya nilai-nilai Islam didalamnya. Nilai-nilai yang terkandung didalamnya adalah meng-atas namaan Allah dalam setiap aktivitas yang dilakukan. Menurut seorang informan adanya basmalah dalam bekulo menunjukkan adanya Islamisasi bekulo. Hal ini disebabkan adannya kebutuhan sepiritual berupa kemantapan hati, karena sesungguhnya pelaku bekulo tersebut adalah muslim.

Dalam pandangan etnografi komunikasi aktivitas bekulo ini merupakan bagian dari pola perilaku komunikasi yang saling berinteraksi, baik secara verbal ataupun nonverbal. Pesan yang disampaikan bersifat khusus dan terarah ke satu tujuan komunikasi.

\section{Betunang}

Betunang merupakan kelanjutan dari upacara adat bekulo. Pada dasamya status pertunangan bujang dan gadis telah diakui dan di sahkan menurut adat melalui ritual bekulo. Menurut Zayadi dan Kadirman, dalam betunang disediakan bahan bahan yang disebut dengan Serana Seranai yang harus disediakan adalah; Setabea, sergayau, byoa tangis tepok, beras kunyit, dupa, kemenyan, tiga buah jeruk nipis dan kue-kue Sedangkan barang yang menjadi tanda betunang adalah, cincin, kain, pakaian atau lainnya dan serawo dengan manisan ditengahnya dan jamuan berupa nasi gulai ayam. Setelah semua siap berkumpulah sanak saudara dari pihak laki-laki dan perempuan yang diahdiri pula oleh rajo, pemuka agama (imam) dan tukang mbigo betunang atau dukun betunang.

Pelaksanaan betunang diawali dengan kata pembukaan dari pembawa acara dengan mengucapkan basmalah. Kemudian dilanjutkan dengan menyuguhkan Sirih izin dari tukang mbigo betunang kepada rajo. Setelah mendapat izin dari rajo, tukang mbigo betunang atau dukun membakar kemenyan dan melakukan tepung tuning.

\section{Sembeak Sujud}

Sembeak Sujud bagi suku Rejang merupakan upacara meminta maaf bagi calon pengantin kepada kedua orang tua dan keluarganya jadi sembeak sujud ini bukanlah sembah sujud layaknya shalat dalam Islam, melainkan tradisi permintaan maaf bagi calon pengantin atas tingkah lakunya selama ini dalam istilah Rejang diungkapkan dengan:

"Tai sembeak sujud lem adat te jang adeba sujud minoi maaf kendei bakea sematen/bakea mengenyan, magea bakea setuwang, bakea penyetuang, leak do indok do bapok, awai o kulo magea leak luwea umeak, magea royotngen prongon bakea stuwang.

Tidak ada waktu khusus ditentukan dalam melakukan tradisi ini. Dapat saja dilakukan sebelum waktu aqad niakah atau sesudahnya. Upacara ini menggunakan sirih untuk menyapa tamu. Alat upacara yang disiapkan sebelum pelaksanaan adalah; bakoa iben atau tukeng lekep dan keracok iben yaitu tempat sirih lengkap dengan isinya, daun sirih kering dan daun sirih hijau sebanyak tujuh lembar, sapu tangan dan ditentukan pula pendamping calon pengantin (tukang dagan) serta pelaku (panitia) sembeak sujud. 
Pelaksanaan upacara sembeak sujud diawali dengan permohonan izin dari pelaku (tukang dagan) kepada rajo. Setelah mendapat izin, tukang dagan mengajak calon pengantin sembeak sujud dengan beberapa tahapan, pertama; tukang dagan menyuguhkan sirih permohonan maaf dari calon pengantin atas kehilafan dan kesalahan selama ini dan memohon diajarkan berbagai hal yang belum diketahui dan meminta penjelasan (ketebiak baso) sebutan pemanggilan seperti paman, bibi calaon pengantin kepada tujuan sembeak sujud. Setelah dijawab oleh tujuan sembeak sujud segala yang diminta, tukang dagan meminta calon pengantin untuk menyembah sebanyak tiga kali. Pada sembahan ketiga, tangan calon pengantin ditutup dengan sapu tangan. Demikin seterusnya persembahan dilakukan pada setiap orang yang dituju sebagai sembeak sujud.

Dalam upacara sembeak sujud terkadang unsur pembelajaran etika dan sopan santun dalam berkomunikasi bagi calon pengantin dalam kehidupan sehari-hari, terutama dalam lingkungan keluargakedua belah pihak. Dalam upacara ini diajarkan kepada kedua calon pengantin sebutan untuk memanggil kedua orang tuanya dan beberapa kekerabatan lainnya baik keatas maupun kebawah atau kesamping berdasarkan siatem kekerabatan keluarga Rejang.

Upacara ini menjadi penting lagi bagi etnis pendatang yang menikah dengan etnis Rejang. Menurut seorang informan "apabila salah dalam menyebut panggilan dengan namanya di anggap tidak berahlak dan tidak beradat". Karena dalam sebutan itu terkandung unsur penghormatan kepada kerabat yang lebih tua dan menyayangi kerabat yang lebih muda dari kedua belah pihak. Jika ditinjau melalui pendekatan teori interksionalisme simbolik, maka sembeak sujud dapat diartikan sebagai penghormatan dan penghargaan yang disampaikan melalui bahasa nonverbal kepada sesepuh adat.

\section{Majok sematen/bakea mengenyan}

Sebelum adat perkawinan pada suku Rejang adalah majok bakea semanten atau baekea mengenyan. Majok semanten adalah tata cara adat mengajak calon pengantin untuk silaturrahmi kerumah calon mertuanya dan berkenalan dengan keluarga besar calon mertuanya. Sebelum pelaksanaan upacara, pihak laki-laki, kutei dan rajo bermusyawarah (basen) untuk mengadakan upacara. Musyawarah tersebut mempersiapkan segala sesuatu yang di butuhkan dalam melakukan upacara meliputi, waktu pelaksanaan, alat-alat upacara dan siapa yang menjadi ketua rombongannya. Setelah ada kesepakatan acara musyawarah selesai. Acara ditutup dengan do'a selamat dan jamuan.

Pada hari pelaksanaan Majok semanten, ketua rombongan (ketuai bathin) meminta wakil pihak perempuan menjemput calon pengantin. Para rombongan menjemput membawa bakul sisrih beserta isinya, kue-kue, selendang, kain, sedingin dan beras kinyit dimasukkan kedalam mangkok putih. Upacara dimulai dengan menyuguh sirih minta izin kepada rajo dan ahli rumah. Setelah mendapat izin dari rajo, ahli rumah menyuguh sirih untuk menyapa tamu sembari memberikan serawo nyoa berupa nasi ketan bercampur gula kelapa. Kemudian wakil dari tamu menyuguhkan sirih kepada rajo untuk menyapa tuan rumah dalam menjemput calon pengantin sesuai kesepakatan. Kemudian wakil tamu menyuguhkan sirih kepada tuan rumah untuk menjelaskan maksud kedatangan mereka.

Apabila calon pengantin ingin berganti pakian, mereka telah menyiapkan beberapa pakian untuk di pakai Amen bakea semanten/mengenyan lok besiuk, dio ade karacok siuk mbin keme, tando arok tando suko, mbeak kumu kidek pnimo" jika calon pengantin sudah siap, dia dibawa menuju rumah calon mertua. Ketika di tangga rumah, calon pengantin di percik dengan air menggunakan daun sergayau dan di taburi beras kunyit disebut dengan tempung. Upacara ini bertujuan untuk menenangkan hati calon pengantin dan menghindari gangguan mahluk halus.setelah sampai di rumah calon mertua, calon pengantin disambut dengan rotan opot oleh calon mertua perempuan dan calon pengantin memegang ujung rotan tersebut dan calon mertua menariknya mengajak kedalam rumah. Sampai dipintu masuk rumah di 
berikan silong dan di tetes matanya dengan byoa tangis tepok dan di suruh sujud didepan pintu. Kemudian di beriminum air umbut pusang dipersilahkan masuk dan duduk ditempat yang sudah disediakan (pedukuak)

Pada saat duduk di pedukuak, calon pengantin menerima beberapa sirih dari keluarga calon mertua. Bakea semanten coa buliak pendukuak ne, kamo si yo bakea temimo iben kundei twei okulo kundei asuak basuak bakea setuang dik diroyot diperongon. Penyuguhan sirih berfungsi memperkenal calon pengantin dengan keluarga besar calon mertua dan memperkenalkan sebagai (sebutan) istilah dalam memanggil keluarga pihak calon mertua. Apabila telah terjadi pemikahan tidak ada kesulitan bagi calon pengantin untuk berkomunikasi dengan keluarga besar pihak calon mertua.

Setelah selesai upacara, ada keluarga pihak calon mertua mengundang calon pengantin ke rumahnya. Bila calon pengantin mendapat izin dari tuan rumah dia dapat memenuhi undangan itu. Apabila penyuguhan sirih tegur sapa telah dianggap cukup di rumah calon mertua, undangan tersebut takperlu dilakukan. Upacara majok semanten ditutup dengan do'a oleh imam (perangkat syara') dan ahli rumah menyampaikan undangan kepada para hadirin untuk hadir pada upacara pemikahan nanti, dan ditutup dengan jamuan.

Selesai jamuan para undangan meninggalkan tempat dan ahli rumah sudah menunggu di depan rumah untuk menyalami para undangan yang pamit pulang. Ngen selesei ne jamuan kutei, selesei kulo ba uleak penyuseak majok bakea semanten/bakea ngenyan melandai. Bakea semantan/bakea ngenyan minoi zin magea bakea stuwangne, awai o kulo magea bakea leak, asuak basuak deroyot deperongon ne, madeak lok belek. Lajau minoi maaf ngen madeak madau majok belek moi umeak ne, waktau kwa'ai ne lok made peng'as pengindau si beduwai o. neak ne senapei tun di temwai oron bakea semantan/bakea ngenyan.

Acara penyuguhan sirih dari keluarga besar calon pengantin memiliki makna signifikan dalam proses pembelajaran etika bergaul dalam bertegur sapa dengan keluarga calon mertua. Calon pengantin diberi bekal untuk melakukan adaptasi terutama dalam pergaulan sehari-hari dengan keluarga calon mertuanya. Bila dalam berkomunikasi dengan keluarga mertua terdapat hal-hal yang tidak sesuai dengan aturan siatem kekerabatan dan adat-istiadat dianggap tidak berahlak dan tidak beradat.

\section{Penentuan Tempat Tinggal setelah Menikah}

Berdasarkan sistem kekerabatan suku Rejang yang patrilineal, adat menetap setalah perkawinan adalah menetap dirumah keluarga laki-laki atau istri mengikuti suami. Sedangkan dari persfektif sistem perkawinan pada awalnya ada dua macam cara menentukannya (asen) yaitu asen beleket dan asen semendo. Kedua asen berfariasi sesuai dengan perkambangan masyarakat dan status sosial seseorang dalam masyarakat.

Asen beleket artinya perempuan masuk dalam keluarga pihak laki-laki, baik tempat tinggalnya maupun siatem kekerabatannya. Asen beleket ini terbagi menjadi dua yaitu leket putus dan leket coa putus (tidak putus). Leket putus uang jemput serta cakkreciknya (barang-barang yang mengiringi uang leket) diambil semua oleh orang tua perempuan. Hubungan perempuan tersebut dengan orang tua dan keluarganya putus. Perempuan tersebut menjadi hak penuh keluarga pihak laki-laki. Sedang leket coa putus pada saat penyerahan uang jemput ada sebagian cokkricek yang tidak di ambil oleh orang tua perempuan. Dalam siatem ini mperempuan masih memiliki ikatan dengan keluarganya. Keluarganya masih memiliki hak untuk meminta bantuan kepada pihak laki-laki.

Asen semendo terbagi kepada empat variasi, pertama; semendo nyep coa bingur artinya hilang tidak terbatas, yaitu laki-laki masuk dalam lingkungan keluarga istrinya. Kedua; semendo nyep/tunakep burung terbang. Artinya laki-laki semendo itu dianggab oleh keluarga istri sebagai seorang yang datang tidak membawa apa-apa. Dia masuk kedalam lingkungan keluarga istrinya. Ketiga; semendo sementaro 
(benggan) artinya semendo tarbatas waktu. Pada awalnya dia masuk kedalam lingkungan keluarga istrinya, tetapi apabila setelah mencukur anaknya dia boleh kembali kepada keluarga asalnya. Keempat; semendo rajo-rajo. Dalam siatem ini masalah tempat tinggal diserahkan sepenuhnya kepada kedua mempelai. Sistem kekerabatannya di akui dari garis keturunan ayah dan ibunya.

Pola menetap setelah perkawinan dalam sistem semendo rajo-rajo menghitung garis keturunan dari pihak ayah dan ibu. Pada dasamya sistem kekerabatan keluarga Rejang bersifat patrilineal, tetapi dalam pelaksanaannya cenderung bersifat bilateral, mengakui garis keturunandari ayah dan ibu. Adat menetap setelah perkawinan dalam siatem ini sesuai dengan kecenderungan siatem kekerabatan yang berlaku sekarang. Akan tetapi dalam aspek-aspek tertentu siatem kekerabatan patrilineal realitas masih kuat.

Adat menetap setelah manikah bagi keluarga Rejang di musyawarahkan dalam upacara bekulo atau barasan. Biasanya menyangkut persoalan kekuasaan berada di tangan suami, tetapi mengenai tempat tinggal dan kekerabatan di musyawarahkan.

Dalam musyawarah kedua belah pihak masing-masing pihak mengharapkan kedua mempelai tinggal bersama mereka. Apabila kedua mempelai memutuskan tinggal disalah satu pihak, pihak keluarga lain merestui. Tidak ada keluarga yang dirugikan dalam sistem semendo rajo-rajo. Berbeda dengan asen beleket yang mengakibatkan terputus hubungan orang tua dengan anak perempuannya. Demikian juga dengan semendo nyep coa bingur dimana laki-laki bertempat tinggal di lingkungan keluarga perempuan, dan apabila istrinya meninggal dunia dia akan dikawin dengan keluarga istrinya.

Kesepakatan yang telah di ambil melalui bekulo tidak pemah disesali kedua belah pihak. Karena sewaktu-waktu dia dapat datang kerumah orang tuanya. Kedua mempelai yang baru menikah ini biasanya dalam waktu yang tidak perlu lama masih tinggal dirumah salah satu orang tuanya, sampai mereka merasa mandiri. Akan tetapi tidak jarang terjadi, bagi keluarga relative mapan, kedua mempelai hanya tinggal beberapa bulan saja dirumah orang tuanya, kemudian pindah kerumahnya sendiri atau mencari rumah kontrakan.

\section{Penentuan Status Harta Bawaan}

Dalam keluarga suku Rejang ada empat jenis harta benda yang terdapat dalam perkawinan yaitu; 1. harta pembujangan 2. Harta penantian atau harta penggadisan, 3. Harta pesuarangan, dan 4. Harta pusaka. Harta pembujangan adalah harta yang di bawa laki-laki pada perkawinannya baik berupa hasil usahanya sendiri selagi bujang maupun harta yang diperolehnya dari hibah atau pusaka yang diterimanya sebelum dia menikah atau semasa pemikahannya. Sedangkan yang dimaksud harta penantian adalah harta yang dibawa oleh si gadis pada perkawinannya dan harta yang diperolehnya dari hibah atau pusaka yang diterimanya sebelum dia menikah atau semasa pemikahannya.

Adapun yang dimaksud harta pesuarangan atau harta pencarian ialah harta yang diperoleh selama masa perkawinan, dengan tidak memperhitungkan apakah harta itu diperoleh atas usaha suami istri masing-masing atau secara bersama, kecuali harta yang diperolah karena warisan atau pemberian langsung dari pihak ketiga kepada suami atau kepada istri saja. Tetapi jika pemberian pihak ketiga di tujukan kepada suami-istri secara bersama, maka harta pemberian tersebut masuk harta pesuarangan. Sedangkan harta pusaka adalah semua harta yang diperoleh karena warisan baik sebelum kawin maupun selama masa perkawinan.

Maksud harta bawaan dalam kajian ini adalah harta pembujangan yaitu harta yang dibawa oleh laki-laki sebelum menikah dan harta penantian atau penggadisan yaitu harta bawaan istri sebelum menikah. Selain itu ada pula harta pusaka yang di peroleh keduanya secara kewarisan sebelum menikah. 
Status harta bawaan relatif berbeda antara yang satu dengan etnis yang lain, karena berbeda adat istiadat dalam siatem perkawianannya.

Dahulu pada keluarga Rejang setatus harta bawaan atau pesuarangan ditentukan oleh sistem atau bentuk perkawianan. Perkawinan jujur merupakan perkawinan sederajat dan hidup bersama sebagai suami istri, maka terdapat harta pesaurangan dan harta bawaan milik suami istri masing-masing. Demikian terhadap perkawinan semendo tambik anak beradat atau semendo rajo-rajo. Karena bentuk perkawinan ini dianggap sebagai perkawinan sederajat.

\section{Bentuk Komunikasi dalam Pelaksanaan Upacara Perkawinan Pada Suku Rejang}

Dalam perkawinan suku Rejang, upacara perkawinan dilakukan dalam dua bentuk kegiatan yaitu; (1) Mengikeak dan Uleak. Uleak dalam Bahasa Rejang lama disebut dengan alek atau umbung, yaitu pekerjaan atau kegiatan yang diatur selama pesta perkawinan berlansung. Persediaan bahan-bahan upacara perkawinan disiapkan oleh ahli rumah (yang mempunyai hajat) di bantu oleh masyarakat setempat dalam sebuah kepanitiaan. Mengikeak, artinya adalah pelaksanaan akad nikah (ijab qabul). Dengan Mengikeak, (akad nikah) menjadi halal hubungan kedua mempelai yang sebelumnya diharamkan secara agama. Dengan terlaksananya upacara Mengikeak, (akad nikah) telah resmi terjalin hubungan kehidupan keluarga. Menurut adat Rejang upacara Mengikeak, harus diikuti dengan Uleak atau umbung (pesta perkawinan) sesuai dengan kemampuan orang yang melaksanakan suatu hajat. Acara jamuan pada hari perkawinan (uleak) disebut dengan jamuan kutei. Jamuan kutei artinya jamuan untuk masyarakat umum. Upacara Perkawinan pada Suku Rejang, juga sering disebut dengan bimbang. Akan tetapi perayaan perkawinan yang

Pada Suku Rejang, pelaksanaan Mengikeak dapat juga si satukan dengan uleak dalam satu hari. Biasanya pelaksanaan Mengikeak dilaksanakan pada pagi hari jam 8.00 WIB, setelah itu dilanjutkan dengan pesta pemikahan. Pelaksanan upacara bentuk ini biasanya lebih simpel. Kecuali orang-orang tertentu seperti pejabat daerah, orang-orang yang mampu, pengusaha sukses, biasanya melakukan kegiatan pesta dalam beberapa hari Upacara pesta biasanya di isi dengan berbagai kegiatan, tarian kejei, Zikir Syarafal anam, pembacaan Marhaban (Al-Barjanzi) Walimatul Urus, dan Hiburan musik; organ tunggal, Nasyid dan lain sebagainya.

Upacara ijab dan qobul pada perkawinan suku Rejang, biasanya di Mulai dengan tertib acara sebagai berikut;

Tembei Mengecek dari tukang Bigo (Protocol/Pembawa acara) acara bekulo dimulai dengan membaca lafadz basmalah yaitu (bismilahirrahmanirrahim);

Iben izin magea rajo oleh perwakilan tuan rumah. Sang wakil membawa sirih dengan berbagai perangkatnya menghadap rajo atau kades meminta izin untuk menyapa dan menanyakan maksud kedatangan pihak laki-laki;

Iben ta'ok tawea yakni menyampaikan sirih menyapa tamu yaitu pihak laki-laki, sekaligus menanyakan maksud kedatangannya. Setelah utusan pihak laki-laki menyampaikan maksudnya ingin bertemu puko emuak, tuan rumah, maka dilanjutkan dengan iben izin kundei mandeak magea rajo.

Iben izin kundai mandiak mageak puko umek, penyampaian sirih minta izin untuk melaksanakan penyerahan pengantin laki kepada pihak pengantin perempun

Wakil pihak perempuan minta izin kepada rajo untuk melanjutkan acara dan menyerahkan kedua calon pengantin untuk di ijab qabulkan kepada penghulu.

Wakil pihak perempuan menyerahkan kedua calon pengantin untuk di ijab qabulkan kepada penghulu. 
Penghulu (KUA) memeriksa biodata pengantin laki pengantin dan perempun, berserta biodata kedua orang tuanya

Pembacaan Kalam Ilahi

di lanjutkan dengan Khutbah Nikah oleh Penghulu

Ijab dan Kabul

Do'a Selamat

Setelah itu kedua pengantin menyalami semua hadirin yang hadir dalam suatu majelis (biasanya diiringi dengan pembacaan solawat badar)

Penutup oleh Protokol

Jamuan umum.

Dalam pelaksanaan upacara Perkawinan suku Rejang tidak di temukan unsur-unsur budaya lokal yang bertentangan dengan Islam. Dalam pelaksanaan upacara tersebut telah terjadi akomodasi nilai-nilai Islam, sehingga simbol-simbol ke-Islaman menjadi dominan mewamai upacara tersebut. Unsur-unsur Islam yang mengalami akomondasi dalam ritual upacara Perkawinan suku Rejang adalah adanya bacaan basmalah, Pembacaan Kitab suci Alqur'an, Khutbah nikah, Ijab Qabul, pembacaan Solawat kepada Nabi dan doa selamat pada kegiatan ritual.

Kegiatan pembacaan,Zikir Syarafal anam, pembacaan Marhaban (Al-Barjanzi) dan ceramah agama (Walimatul Urus) pada saat prosesi setelah akad nikah adalah indikasi yang cukup kuat bahwa telah terjadinya akomodasi nilai-nilai Islam, sehingga simbol-simbol ke-Islaman menjadi dominan mewamai upacara perkawinan tersebut.

Menurut Kadirman, adat istidat perkawinan Suku Rejang hanya mengatur prosesi adat sebelum terjadinya akad nikah/ ijab qabul, agar lebih baik dan bermartabat, dan tidak menginterpensi wilayah sakral agama seperti pelaksanaan ijab dan qabul berdasarkan tata cara syariat Islam. Menurutnya inilah makna dari ungkapan adat Bersendikan Syara'dan Syara" bersendikan Kitabullah.

Perkawian dalam Islam adalah peristiwa sakral yang dikenal degan Mistaqon qholiza adalah ikatan yang kokoh, perjanjian yang berat antara sesorang laki-laki dan perempuan. Perkawinan juga merupakan peristiwa yang secara formal mempertemukan sepasang mempelai atau sepasang calon suami-istri di hadapan penghulu atau kepala agama tertentu, para saksi, dan sejumlah hadirin untuk kemudian disahkan secara resmi sebagai suami-istri dengan upacara-upacara atau ritus-ritus tertentu.

\section{SIMPULAN}

Bentuk komunikasi dalam upacara adat suku Rejang dapat diketahui dari pola perkawinan eksogami yang pada awalnya berbentuk kawin jujur dan semendo (asen beleket dan asen semendo) Asen Beleket ini terbagi dua yaitu; (leket putus dan leket coa putus.) Perkawinan Semendo terbagi menjadi dua bagian yaitu Semendo Ambil Anak (tambik Anak) dan Semendo rajo-rajo. Sistem Semendo ambil anak terbagi dua yaitu; Semendo ambil anak tidak beradat disebut juga Semendo menangkap hurung terbang (nyep tunakep burung terbang) dan Semendo ambil anak beradat. Selain kedua bentuk Semendo tersebut, dahulu pada masyarakat Rejang juga dikenal Semendo bayar utang dan Semendo langew jio (lalat Hijau). Namun Perkawinan yang lazim dilakukan oleh suku Rejang saat ini adalah bentuk perkawinan Semendo rajo-rajo. Sementara perkawinan jujur dan semendo ambil anak dengan segala variasinya saat ini sudah tidak berlaku. Sehingga dapat disimpulkan bahwa dari dua pola perkawinan ini, terdapat dua bentuk komunikasi yang digunakan yakni komunikasi verbal dan nonverbal. Dua bentuk komunikasi ini dapat dilihat dari tahapan-tahapan sebelum dan sesudah perkawinan seperti; mediak, bekulo, betunang, dan 
sembeak sujud dan majok sematen/bakea mengenyan tahapan-tahapan sebelum perkawinan ini menunjukkan bentuk komunikasi verba dan nonverbal yang menyatu dalam satu rangkaian adat.

Norma komunikasi yang terbentuk dalam upacara adat perkawinan suku Rejang ini dapat diketahui dari tiga kegiatan atau tahapan dalam proses mengasen atau meminang, yaitu; semeluak asen, tematoa asen dan jemejei asen. Semeluak maksudnya, keluarga laki-laki menanyakan kepada pihak perempuan dapat atau tidak hubungan anak ini diteruskan. Sembari meneliti dari dekat tentang keadaan calon menantunya. Kegiatan ini dalam istilah Rejang disebut dengan mengisik. Kedatangan pihak laki-laki disambut baik keluarga perempuan. Dalam kesempatan ini pihak laki-laki menyampaikan maksudnya. Bila ada kesepakatan wakil pihak laki-laki mengatakan "kami susul lagi nanti" (keme tematoa kedong igei), maka terjadilah kegiatan berikutnya yang disebut dengan temotoa asen yaitu menyusul hasil kesepakatan waktu semeluak asen. Tujuan upacara ini untuk mengambil keputusan mufakat antara kedua keluarga tentang jumlah uang hantaran dengan cakkriciknya, status perkawinan menurut adat dan pelaksanaan upacara perkawinan. Konteks norma komunikasi dapat juga dilihat dalam proses hantaran. Kegiatan tersebut menunjukkan adanya norma komunikasi yang terbentuk yakni dari diadakannya musyawarah penentuan hantaran yang dilaksanakan oleh dua keluarga yaitu pihak laki-laki dan perempuan dalam upacara tematoa asen, yaitu salah satu tahap dalam proses pelamaran (seperti disebutkan diatas). Pada pertemuan kedua belah pihak ini diwakili jururasan masing-masing keluarga. Wakil jururasan harus memiliki kemampuan dalam mengadakan negoisasi. Ketidakmampuan dalam bidang ini bukan tidak mungkin uang dan barang hantaran menjadi lebih besarm karena ketidakmampuan mengantisipasi permintaan pihak perempuan. Apabila terdapat kesulotan dalam memutuskan, jururasan akan bermusyawarah secara intemal dengan keluarga masing-masing.

Sehingga dapat disimpulkan bahwa, tidak boleh sembarang orang yang bisa menjadi wakil jurusan. Norma komunikasi yang dibangun dalam proses ini mengharuskan pihak laki-laki atau perempuan harus menunjuk salah satu wakil yang mempunyai kemampuan komunikasi dan negoisiasi yang baik.

\section{DAFTAR PUSTAKA}

Abdul Aziz Muhammad Azzam, A. W. S. H. (2009). Fiqih Munakahat. Jakarta: Amzah.

Ahwan, Z. (2012). Studi Fenomenologis: Perbedaan Budaya Berkomunikasi Antara Masyarakat Pendatang Keturunan Arab (Oyek) dengan Penduduk Asli Bangil Kabupaten Pasuruan. Jurnal Kebangsaan, 5(1).

Aini, N. (2009). Interaksi Masyarakat Pribumi dengan Masyarakat Pendatang dalam Membangun Toleransi Beragama di Desa Tonjong. Jakarta: UIN Syarif Hidayatullah.

Hamzah, Z. (2010). Islam dalam Perpektif Budaya Lokal Studi tentang Ritual Siklus Kehidupan Keluarga Suku Rejang di Kabupaten Rejang Lebong. Jakarta: UIN Syarif Hidayatulah.

Koentjaraningrat. (1982). Masalah-Masalah Pembangunan. Jakarta: Bunga Rampai Antropologi Terapan. Jakarta: LP3ES.

Morissan. (n.d.). Teori Komunikasi. Bogor: Ghalia Indonesia.

Mudjiyanto, B. (2009). Metode Etnografi Dalam Penelitian Komunikasi. Komunikasi Massa. Jakarta: Depkominfo RI.

Mulyana, D. (2006). Pengantar Ilmu Komunikasi. Bandung: Remaja Rosdakarya.

Munir, M. (2015). Metode Dakwah. Jakarta: Prenamedia Group.

Muridan. (2007). Islam dan Budaya Lokal: Kajian Makna Simbol dalam Perkawinan Adat Keraton. Jurnal Studi Islam Dan Budaya, 5(1).

Noer Aly, H. (2007). Potret Kantor Wilayah Departemen Agama Propinsi Bengkulu dalam Islam di Bengkulu. Bengkulu: Kantor Wilayah Departemen Agama Bengkulu.

Soekanto, S. (2007). Sosiologi Suatu Pengantar. Jakarta: Raja Grafindo Persada.

Sugiyono. (2013). Memahami Penelitian Kualitatif. Bandung: CV. Alfabeta. 